\title{
RESPONSE OF SOME SWEET POTATO LINES TO BIOFERTILIZATION UNDER DRIP IRRIGATION IN NEWLY RECLIMED SOIL \\ Badawy, A.S.*; M.H. Hosseny ${ }^{\star *}$ and H. E. Mohamed* \\ * Hort. Res. Institute A.R.C. Giza, Egypt \\ ${ }^{* \star}$ Hort. Dept., Fac. Agric., Sohag Uinv.
}

\begin{abstract}
This work was carried out during the two summer seasons of 2004 and 2005 at Arab El-Awammer Research Station; Center (A.R.C.); Assiut Governorate, Egypt, to study the effect of using biofertilization to decreased the chemical fertilizer rates on sweet potato plants grown in newly reclaimed soil under drip irrigation. Four lines of sweet potato (Assiut 201,202,203 and 204) and five treatments of nitrogen zero, $25,50,75$ and $100 \%$ from the recommended dose used with an equal amount of Biogen fertilizers $(2 \mathrm{Kg})$ in our study. The results indicated that the treatment of $(100 \% \mathrm{~N}+2 \mathrm{Kg}$ Biogen) gave the best results in most studied characters and also lines Assiut 201 and 204 were the best lines under experiment condition for most studied characters. The $100 \% \mathrm{~N}$ level with Biogen fertilizer gave the best results in most characters. Also the interaction between (100\%N +Biogen) and line Assiut 204 gave the highest plant height and highest number of branches while the interaction between $100 \% \mathrm{~N}+$ Biogen and line Assiut 201 gave the best number of marketable storage root/plant, weight of marketable storage root/plant, root length and root diameter. While the high starch root percentage was obtained from interaction between 25 and 75\%N+Biogen and line Assiut 201.
\end{abstract}

\section{INTRODUCTION}

Sweet potato (Ipomoea batats L.) is one of most popular vegetable crop in Egypt. It has been cultivated for both human food consumption and starch production, moreover the foliage are used for animal feed. For increasing its total productivity to meet the increment in the human population, that could be achieved through increasing cultivated area especially on sandy soil .The continuous increase in the costs of chemical fertilizers and environmental pollution problems restrict the application of sufficient amount. Thus, it has become essential to use untraditional fertilizers as substitutes or supplements for chemical fertilizers.

Previous workers had shown that nitrogen particularly in relatively high doses could enhance sweet potato tuber yield (Lee Hsinchen et al.,1996; Taufatofua et al.,1996; Hartemink et al.,2001; Marti and Mills, 2002; Arsenault et al.,2001 and Belanger et al.,2002), tuber size and weight (Arsenault et al.,2001 and Belanger et al.,2002).

Many investigators mentioned that using biofertilizers gave the best results in many vegetables. For instance, Pandey and Kumar (1989) found that biofertilizer application with and without application of NPK increased yield of several vegetables. Saber and Gomaa (1993) stated that application of $1 / 3$ the recommended NPK rate and inoculation with a mixed biofertilizers increased plant dry weight in tomato plants. Sood et al. (1994) showed that 
the tuber yield and dry matter increased significantly with application of FYM. Singh et al., (1996) found that the application of 15 ton FAM+100Kg $\mathrm{P}_{2} \mathrm{O}_{2}$ was more effective on tuber potato yield than using FAM alone. El-Gamal (1996) studied response of potato in the newly reclaimed areas to mineral nitrogen fertilizer levels and nitrogen fixing biofertilizer Halex2. He found that increasing $\mathrm{N}$ application rate or inoculation with Halex2 resulted in taller plants with higher leaf $\mathrm{N}$ contents. Dry matter, protein contents of tubers, exportable and total yield were generally increased with application of Halex2 or by increasing $\mathrm{N}$ application rate. Ashour and Sarhan (1998) reported that in potato plants application of organic with each other or with inorganic fertilizers increased yield, weight and number of potato tubers. Kamla(1999) studied the effect of bio-fertilizers on potato production. He found that tuber yield was highest with increasing biofertilizers. Abou El-Salehein et al.,(1999) found that in potato plants application of chicken manure significantly increased number of tuber/plant, average tuber weight, total yield and total carbohydrates and total sugars. El-Banna and Tolba (2000) found that using biofertilizers increased plant height, number and weight was of tubers/plant, dry matter of tubers and total tuber yield as well as decreased the nitrate concentration in potato tubers. El-Banna and Abd El-Salam(2000) found that tuber potato weight increased with increasing farmyard manure. El-Banna et al., (2001) studied the effect of bio-organic fertilization on potato plants. They found that application of organic fertilizer together led to significant increases in plant height, foliage fresh weight/plant, total tuber yield weight and number of tuber/plant. Awad et al.,(2002) studied the effect of used FYM in potato fertilizers. The results indicated that the application of FAM induced significant increases in vegetative growth parameters(plant height, foliage fresh weight/plant and foliage dry weight), total tuber yield ,number of tubers/plant, tuber average weight, tuber dry matter and percentage of starch. El-Kader (2002) reported that plant height, foliage fresh and dry weight, number and weight of tubers/plant, dry weight and total tuber yield were increased due to FAM application. El-Seifi et al.,(2004) found that combination between $\mathrm{N}$ level $120 \mathrm{~kg}$ and biofertilizer gave the best results in productivity and quality of Chinese garlic under sandy soil conditions.

The present work aimed mainly to study the effect of using biofertilization to decrease the chemical fertilizer rates on sweet potato plants grown in sandy soil under drip irrigation.

\section{MATERIALS AND METHODS}

Two field experiments were performed during the two successive seasons of 2004 and 2005 at Arab El-Awammer Research Station; Center (A.R.C.); Assiut Governorate ,Egypt, to study the effect of Biogen as biofertilization on vegetative characters and yield and its components of 4 sweet potato lines i.e., Assiut 201, Assiut 202, Assiut 203 and Assiut 204 under drip irrigation system in newly reclaimed soil. The physical and chemical properties of experimental soil are presented in Table1. Moreover, 
the characters of four sweet potato lines in this study are presented in Table 2.

The experiment system was split-plot in randomized complete blocks design with four replicates. The main plots were assigned for biofertilization treatment while sweet potato lines occupied the sub-plot. Each experimental plot was $10.5 \mathrm{~m}^{2}$. It contains three dipper irrigation lines with $6 \mathrm{~m}$ long and 70 $\mathrm{cm}$ wide. One-dripper line was used for measuring the vegetative growth characters, while the other two lines were used for measuring the yield and its components. The planting date was on 25 April in both summer seasons. All experimental units received equal recommended amounts of potassium sulphate $\left(48 \% \mathrm{k}_{2} \mathrm{O}\right)$ and calcium superphosphate $\left(15.5 \% \mathrm{P}_{2} \mathrm{O}_{5}\right)$ with dose $200 \mathrm{Kg} \mathrm{k} 2 \mathrm{O} / \mathrm{feddan}$ and $300 \mathrm{Kg} \mathrm{P}_{2} \mathrm{O}_{5} /$ feddan. Both third of $\mathrm{K}_{2} \mathrm{O}$ and all amounts of $\mathrm{P}_{2} \mathrm{O}_{5}$ was added at soil preparation while the two thirds of $\mathrm{K}_{2} \mathrm{O}$ were added eight portion weekly beginning 15 day after transplanting. The recommended dose of $\mathrm{N}$ was $300 \mathrm{Kg} / \mathrm{feddan}$ (Ammonium sulphate 20.6\%). This experiment included five treatments as follow:-

(1) $2 \mathrm{Kg}$ Biogen fertilizer/fed $+0 \%$ from recommended dose of $\mathrm{N}$

(2) $2 \mathrm{Kg}$ Biogen fertilizer/fed $+25 \%$ from recommended dose of $\mathrm{N}$

(3) $2 \mathrm{Kg}$ Biogen fertilizer/fed $+50 \%$ from recommended dose of $\mathrm{N}$

(4) $2 \mathrm{Kg}$ Biogen fertilizer/fed $+75 \%$ from recommended dose of $\mathrm{N}$

(5) $2 \mathrm{Kg} \mathrm{Biogen}$ fertilizer/fed $+100 \%$ from recommended dose of $\mathrm{N}$

Table 1: Some physical and chemical properties of a representative soil sample used in the experimental site

\begin{tabular}{|c|c|c|c|c|c|c|c|c|c|}
\hline \multirow[t]{2}{*}{ Season } & \multirow[t]{2}{*}{ PH } & \multirow[t]{2}{*}{ EC } & \multirow[t]{2}{*}{$\begin{array}{c}\mathrm{CacO}_{3} \\
\%\end{array}$} & \multicolumn{4}{|c|}{ Soluble cations $\mathrm{meq} / \mathbf{1 0 0 \mathrm { g }}$ soil } & \multicolumn{2}{|c|}{$\begin{array}{c}\text { Soluble anions } \\
\mathrm{meq} / 100 \mathrm{~g} \text { soil }\end{array}$} \\
\hline & & & & $\mathbf{C a}^{+2}$ & $\mathrm{Mg}^{+2}$ & $\mathrm{Na}^{+1}$ & $\mathrm{~K}^{+1}$ & $\mathrm{CO}_{3}+\mathrm{HCO}_{3}$ & $\mathrm{CL}$ \\
\hline 2004 & 8.21 & 0.59 & 27.33 & 0.30 & 0.24 & 0.11 & 0.01 & 0.32 & 0.28 \\
\hline 2005 & 8.43 & 0.77 & 32.15 & 0.33 & 0.28 & 0.03 & 0.03 & 0.38 & 0.22 \\
\hline \multirow[t]{2}{*}{ Season } & \multicolumn{3}{|c|}{ Available nutrients } & \multicolumn{3}{|c|}{ Mechanical analysis \% } & \multirow{2}{*}{\multicolumn{3}{|c|}{ Soil texture }} \\
\hline & $\mathrm{N} \%$ & P PPM & $\mathbf{K}$ & Sand & Silt & Clay & & & \\
\hline 2004 & 0.06 & 5.14 & 0.14 & 85.4 & 8.7 & 5.9 & \multirow{2}{*}{\multicolumn{3}{|c|}{ Sandy }} \\
\hline 2005 & 0.04 & 4.88 & 0.12 & 87.2 & 7.2 & 5.6 & & & \\
\hline
\end{tabular}

Table 2:Characters of four sweet potato lines in this study

\begin{tabular}{|c|c|c|c|}
\hline \multirow{2}{*}{ No. } & \multirow{2}{*}{ Lines } & \multicolumn{2}{|c|}{ Description of storage root- color } \\
\cline { 3 - 4 } & Outside & Flesh \\
\hline 1 & Assiut 201 & Red & White \\
2 & Assiut 202 & White & White \\
3 & Assiut 203 & Pole red & Whitish \\
4 & Assiut 204 & Red & Whitish \\
\hline
\end{tabular}

During the two experimental seasons the following data were recorded 1 -Vegetative characters i.e., number of branches/plant, the main stem length $(\mathrm{cm})$ and weight of vines/plant $(\mathrm{kg})$.

2-Yield and its components i.e., number of marketable storage root/plant, weight of marketable storage root/plant $(\mathrm{Kg})$, root length $(\mathrm{cm})$ and root diameter(cm). 
3-Chemical characters i.e., Dry matter percentage, root crude fibers content $(\mathrm{g} / 100 \mathrm{~g})$ and starch root percentage.

Statistical analysis: all obtained data were subjected to statistical analysis of variances, and the least significant differences (L.S.D) at $5 \%$ level of probability were calculated as mentioned by Gomez and Gomez (1984).

\section{RESULTS AND DISCUSSION}

\section{I-Vegetative characters}

1-Number of branches/plant

Data in Table 2 indicated that there are highly significant differences among the five levels of fertilizers in this character in both seasons. The treatment 5 gave the highest values in this trait. Line Assiut 204 was significant higher than other lines in this trait in both seasons. Also the interaction between fertilizer treatment 5 and line 204 was significantly higher than other interactions in this character.

2-The main stem length $(\mathrm{cm})$

Presented data in Table 2 indicate that there are significant differences among the five treatments of fertilizer in this trait. Also the high main stem length was obtained from treatment 5 . There are significant differences between the four potato lines in this character and line Assiut 204 gave the highest values in the two seasons. The interaction between line Assiut 204 and treatment 5 fertilizer gave the highest values in both seasons in this character.

3- Weight of vines/plant $(\mathrm{kg})$.

Results in table 2 illustrate that used the fertilizer of treatment 5 gave the highest values in this character and significantly higher than other fertilizers treatments. Line Assiut 202 was the best lines for weight of vines/plant. The interaction between treatment 5 and line 202 was highly significant higher than other interactions in this character.

Our results indicated that the high treatment of nitrogen with Biogen gave the best results in vegetative characters. These results are in accordance with those of (Lee Hsinchen et al.,1996; Taufatofua et al.,1996; Hartemink et al.,2001; Marti and Mills, 2002; Asrenault et al.,2001 and Belanger et al.,2002). Also, application the biofertilizer in sweet potato production gave the best results for vegetative characters and these results agree with those reported by Saber and Gomaa (1993), El-Banna and Tolba (2000), El-Banna et al., (2001) and Awad et al.,(2002).

\section{II-Yield and its components}

1-Number of marketable storage root/plant

Results outlined in Table 3 declare that the highest value of this character was obtained from the fertilizer with treatment 5 in both seasons . Line Assiut 201 gave the highest values in this character. Also there were highly significant differences among the interactions between potato lines and the five treatments of fertilizers in this trait. The interaction between treatment 5 and line Assiut 201 gave the highest value for number of mar marketable storage root/plant. 
2-Weight of marketable storage root/plant

Data in Table 3 elucidate that there are highly significant differences among the five treatments of fertilizer in this character and the highest value was obtained from treatment 5 in both seasons. There are high significant differences between the four potato lines in this trait and the line Assiut 201 gave the highest values in both seasons. Also there were highly significant differences among the interactions between potato lines and the five treatments of fertilizers in this trait. The interaction between treatment 5 and line Assiut 201 gave the best results in this character.

Table 3: Response of sweet potato lines to biofertilizer on vegetative characters during seasons 2004 and 2005.

\begin{tabular}{|c|c|c|c|c|c|c|}
\hline Characters & $\begin{array}{r}\text { Num } \\
\text { branch }\end{array}$ & $\begin{array}{l}\text { r of } \\
\text { /plant }\end{array}$ & $\begin{array}{r}\text { The } n \\
\text { len }\end{array}$ & $\begin{array}{l}\text { stem } \\
\text { cm) }\end{array}$ & weight & es/plant \\
\hline N Levels & 2004 & 2005 & 2004 & 2005 & 2004 & 2005 \\
\hline (1) $0 \% \mathrm{~N}+2 \mathrm{~kg}$ Biogen & 5.250 & 4.563 & 162.9 & 167.4 & 2.756 & 2.756 \\
\hline (2) $25 \% \mathrm{~N}+2 \mathrm{~kg}$ Biogen & 6.938 & 6.813 & 161.3 & 161.9 & 3.813 & 3.881 \\
\hline (3) $50 \% \mathrm{~N}+2 \mathrm{~kg}$ Biogen & 7.063 & 7.313 & 164.2 & 165.2 & 3.921 & 3.909 \\
\hline (4) $75 \% N+2 k g$ Biogen & 6.750 & 7.563 & 165.7 & 166.4 & 4.095 & 4.089 \\
\hline (5) $100 \% \mathrm{~N}+2 \mathrm{~kg}$ Biogen & 8.313 & 8.250 & 175.8 & 176.0 & 5.712 & 5.756 \\
\hline L.S.D & 0.774 & 0.745 & 1.586 & 5.400 & 0.070 & 0.062 \\
\hline Lines & & & & & & \\
\hline (L1) Assiut 201 & 7.200 & 7.300 & 124.5 & 127.5 & 3.277 & 3.268 \\
\hline (L2) Assiut 202 & 5.450 & 5.250 & 163.5 & 163.6 & 5.306 & 5.336 \\
\hline (L3) Assiut 203 & 6.300 & 6.550 & 184.3 & 186.0 & 4.262 & 4.319 \\
\hline (L4) Assiut 204 & 8.500 & 8.500 & 191.8 & 192.5 & 3.393 & 3.391 \\
\hline L.S.D & 0.490 & 0.539 & 1.465 & 4.530 & 0.065 & 0.097 \\
\hline INTERACTIONS & & & & & & \\
\hline N1x L1 & 5.250 & 4.750 & 117.3 & 132.8 & 2.658 & 2.625 \\
\hline $\mathrm{N} 1 \times \mathrm{L} 2$ & 4.000 & 3.500 & 167.4 & 167.3 & 3.838 & 3.825 \\
\hline N1x L3 & 4.750 & 4.250 & 176.4 & 180.1 & 2.565 & 2.625 \\
\hline N1x L4 & 7.000 & .5 .750 & 187.5 & 189.6 & 1.963 & 1.950 \\
\hline N2x L1 & 7.000 & 7.500 & 123.1 & 122.1 & 2.963 & 2.958 \\
\hline $\mathrm{N} 2 \times \mathrm{L} 2$ & 6.000 & 5.750 & 158.6 & 159.0 & 4.915 & 5.048 \\
\hline N2x L3 & 6.000 & 6.000 & 177.0 & 178.6 & 4.190 & 4.355 \\
\hline $\mathrm{N} 2 \times \mathrm{L} 4$ & 8.750 & 8.000 & 186.6 & 187.9 & 3.183 & 3.165 \\
\hline N3x L1 & 7.500 & 7.250 & 126.1 & 125.8 & 3.258 & 3.250 \\
\hline N3x L2 & 5.250 & 5.500 & 158.4 & 160.4 & 5.113 & 5.125 \\
\hline N3xL3 & 7.000 & 7.500 & 182.1 & 184.1 & 4.013 & 4.038 \\
\hline N3xL4 & 8.500 & 9.000 & 190.3 & 190.5 & 3.273 & 3.225 \\
\hline N4xL1 & 7.500 & 8.500 & 123.1 & 123.6 & 3.300 & 3.255 \\
\hline N4xL2 & 5.750 & 5.750 & 162.1 & 160.9 & 5.563 & 5.533 \\
\hline N4xL3 & 6.250 & 7.500 & 185.5 & 188.9 & 4.218 & 4.253 \\
\hline N4XL4 & 7.500 & 8.500 & 192.1 & 192.4 & 3.300 & 3.318 \\
\hline N5xL1 & 8.750 & 8.500 & 133.0 & 133.3 & 4.178 & 4.250 \\
\hline N5xL2 & 6.250 & 5.750 & 170.8 & 170.3 & 7.100 & 7.150 \\
\hline N5xL3 & 7.500 & 7.500 & 197.4 & 198.1 & 6.323 & 6.325 \\
\hline N5xL4 & 10.750 & 11.250 & 202.3 & 202.3 & 5.248 & 5.298 \\
\hline L.S.D & & 1.206 & 3.275 & & 0.146 & 0.217 \\
\hline
\end{tabular}

3- Root length $(\mathrm{cm})$ and Root diameter $(\mathrm{cm})$.

Data in Table 3 demonstrate that there are significant differences among the five treatments of fertilizers in root length and the highest values were obtained from treatment 5 and there are no differences between this treatment and treatments 3and 4. Line Assiut 201 gave higher value than the 
Badawy, A.S. et al.

other four potato lines in this trait. Also the differences due to the interaction between the fertilizer of treatment 5 and line Assiut 201 was significantly higher than other interactions in both seasons.

The results indicated that using biofertilizer in combination with of NPK increased yield characters in sweet potato production and these results agree with those reported by Pandey and Kumar (1989), Sood et al. (1994), Singh et al., (1996), El-Gamal (1996), Ashour and Sarhan (1998), Kamla(1999) Abou El-Salehein et al.,(1999), El-Banna and Tolba (2000), El-Banna and Abd El-Salam(2000), El-Banna et al., (2001), Arsenault et al.,2001 and Belanger et al.,2002.

\section{III-Chemical characters}

\section{1- Dry matter percentage}

Data in Table 4 indicated that there is no significant difference among the five treatment of fertilizer in this trait. Line Assiut 202 gave the highest values of dry matter percentage and was highly significant differences among other lines in this trait. The results of the interaction between the potato lines and five treatment of fertilizer indicated that the highest values were obtained from the interaction between line Assiut 201 and treatment 2 in both seasons.

2- Root crude fibers content $(\mathrm{g} / 100 \mathrm{~g})$

Data in Table 4 elucidate that there are highly significant differences among the five treatments of fertilizer in this character and the highest value was obtained from treatment 1 in both seasons. There are high significant differences between the four potato lines in this trait and the line Assiut 202 gave the highest values in both seasons. Also there were highly significant differences among the interactions between potato lines and the five treatments of fertilizers in this trait. The interaction between treatment 2 and line Assiut 202 gave the best results in this character.

3- Starch root percentage.

Presented data in Table 4 indicate that there are significant among the five treatments of fertilizer in this trait. Also the high value of starch root percentage was obtained from treatment 1 . There are significant between the four potato lines in this character and line Assiut 201 gave the highest values in the two seasons. The interactions between line Assiut 204 and treatment 1 and Assiut 201 and treatment 4 fertilizer gave the highest values in both seasons in this character.

Our results are in harmony with those by Sood et al. (1994), El-Gamal (1996), Abou El-Salehein et al.,(1999) El-Banna and Tolba (2000), El-Kader (2002), El-Seifi et al.,(2004). 
J. Agric. Sci. Mansoura Univ., 32 (4), April, 2007

Table 4: Response of sweet potato lines to biofertilizer on yield and its components characters during seasons 2004 and 2005.

\begin{tabular}{|c|c|c|c|c|c|c|c|c|}
\hline Characters & \multicolumn{2}{|c|}{$\begin{array}{c}\text { Number of } \\
\text { storage } \\
\text { root/plant }\end{array}$} & \multicolumn{2}{|c|}{$\begin{array}{l}\text { Weight of } \\
\text { storage } \\
\text { root/plant }\end{array}$} & \multicolumn{2}{|c|}{ Root length } & \multicolumn{2}{|c|}{ Root diameter } \\
\hline N Levels & 2004 & 2005 & 2004 & 2005 & 2004 & 2005 & 2004 & 2005 \\
\hline (1) $0 \% \mathrm{~N}+2 \mathrm{~kg}$ Biogen & 1.688 & 1.813 & 0.294 & 0.326 & 11.16 & 11.18 & 3.363 & 3.331 \\
\hline (2) $25 \% \mathrm{~N}+2 \mathrm{~kg}$ Biogen & 3.428 & 3.813 & 0.809 & 0.805 & 14.54 & 14.44 & 3.831 & 3.838 \\
\hline (3) $50 \% \mathrm{~N}+2 \mathrm{~kg}$ Biogen & 4.875 & 4.813 & 1.073 & 1.116 & 15.16 & 15.20 & 4.013 & 4.050 \\
\hline (4) $75 \% N+2 k g$ Biogen & 5.500 & 5.313 & 2.238 & 2.288 & 15.33 & 15.48 & 4.006 & 4.006 \\
\hline (5) $100 \% \mathrm{~N}+2 \mathrm{~kg}$ Biogen & 5.813 & 5.625 & 2.509 & 2.524 & 15.74 & 15.71 & 4.144 & 4.194 \\
\hline L.S.D & 0.474 & 0.360 & 0.050 & 0.029 & 0.163 & 0.112 & 0.075 & 0.079 \\
\hline Lines & & & & & & & & \\
\hline (L1) Assiut 201 & 5.250 & 5.200 & 1.988 & 2.023 & 15.17 & 15.19 & 5.860 & 5.850 \\
\hline (L2) Assiut 202 & 3.650 & 3.850 & 0.769 & 0.802 & 12.77 & 12.85 & 2.370 & 2.355 \\
\hline (L3) Assiut 203 & 4.700 & 4.850 & 1.636 & 1.667 & 14.74 & 14.74 & 4.275 & 4.310 \\
\hline (L4) Assiut 204 & 3.450 & 3.200 & 1.146 & 1.156 & 14.88 & 14.85 & 2.980 & 3.020 \\
\hline L.S.D & 0.396 & 0.408 & 0.035 & 0.030 & 0.098 & 0.115 & 0.056 & 0.061 \\
\hline INTERACTIONS & & & & & & & & \\
\hline N1x L1 & 2.250 & 2.500 & 0.575 & 0.725 & 11.03 & 11.15 & 5.050 & 5.000 \\
\hline $\mathrm{N} 1 \times \mathrm{L} 2$ & 1.500 & 2.250 & 0.175 & 0.175 & 9.10 & 9.08 & 2.075 & 2.050 \\
\hline N1x L3 & 1.500 & 1.250 & 0.215 & 0.223 & 12.08 & 12.10 & 3.575 & 3.575 \\
\hline N1x L4 & 1.500 & 1.250 & 0.210 & 0.180 & 12.43 & 12.40 & 2.750 & 2.700 \\
\hline N2x L1 & 3.750 & 4.000 & 1.100 & 1.050 & 16.10 & 16.08 & 5.600 & 5.650 \\
\hline N2x L2 & 3.500 & 3.750 & 0.650 & 0.625 & 13.40 & 13.50 & 2.450 & 2.470 \\
\hline N2x L3 & 4.000 & 5.250 & 0.750 & 0.825 & 15.30 & 15.13 & 4.325 & 4.300 \\
\hline N2xL4 & 2.500 & 2.250 & 0.738 & 0.720 & 13.38 & 13.08 & 2.950 & 2.925 \\
\hline N3x L1 & 5.500 & 5.250 & 1.100 & 1.153 & 16.00 & 16.05 & 6.000 & 6.000 \\
\hline N3x L2 & 4.500 & 4.250 & 0.650 & 0.700 & 13.45 & 13.45 & 2.500 & 2.450 \\
\hline N3xL3 & 5.500 & 5.500 & 1.788 & 1.860 & 15.13 & 15.15 & 4.475 & 4.625 \\
\hline N3xL4 & 4.000 & 4.250 & 0.753 & 0.753 & 16.08 & 16.16 & 3.075 & 3.125 \\
\hline N4xL1 & 7.000 & 6.750 & 3.550 & 3.563 & 16.18 & 16.18 & 6.150 & 6.125 \\
\hline N4xL2 & 4.500 & 4.500 & 1.050 & 1.175 & 13.83 & 14.18 & 2.300 & 2.300 \\
\hline N4xL3 & 6.000 & 6.000 & 2.325 & 2.363 & 15.18 & 15.33 & 4.500 & 4.500 \\
\hline N4xL4 & 4.500 & 4.000 & 2.025 & 2.050 & 16.13 & 16.25 & 3.075 & 3.100 \\
\hline N5xL1 & 7.750 & 7.500 & 3.613 & 3.625 & 16.53 & 16.48 & 6.500 & 6.475 \\
\hline N5xL2 & 4.250 & 4.500 & 1.320 & 1.335 & 14.08 & 14.03 & 2.525 & 2.500 \\
\hline N5xL3 & 6.500 & 6.250 & 3.100 & 3.063 & 16.00 & 16.00 & 4.500 & 4.550 \\
\hline N5xL4 & 4.750 & 4.250 & 2.003 & 2.075 & 16.38 & 16.35 & 3.050 & 3.250 \\
\hline L.S.D & 0.886 & 0.915 & 0.078 & 0.067 & 0.219 & 0.256 & 0.125 & 0.134 \\
\hline
\end{tabular}


Badawy, A.S. et al.

Table 5: Response of sweet potato lines to biofertilizer on chemical characters during seasons 2004 and 2005.

\begin{tabular}{|c|c|c|c|c|c|c|}
\hline Characters & Dry mat & content & $\begin{array}{l}\text { root } \mathrm{Cl} \\
\text { conte }\end{array}$ & $\begin{array}{l}\text { fibers } \\
/ 100 \mathrm{~g})\end{array}$ & $\begin{array}{l}\text { star } \\
\text { per }\end{array}$ & $\begin{array}{l}\text { root } \\
\text { age }\end{array}$ \\
\hline N Levels & 2004 & 2005 & 2004 & 2005 & 2004 & 2005 \\
\hline (1) $0 \% \mathrm{~N}+2 \mathrm{~kg}$ Biogen & 28.80 & 28.81 & 1.641 & 1.641 & 10.99 & 10.99 \\
\hline (2) $25 \% \mathrm{~N}+2 \mathrm{~kg}$ Biogen & 28.59 & 28.58 & 1.631 & 1.635 & 10.96 & 10.96 \\
\hline (3) $50 \% \mathrm{~N}+2 \mathrm{~kg}$ Biogen & 28.35 & 28.44 & 1.632 & 1.630 & 10.96 & 10.96 \\
\hline (4) $75 \% \mathrm{~N}+2 \mathrm{~kg}$ Biogen & 28.36 & 28.38 & 1.623 & 1.625 & 10.94 & 9.69 \\
\hline (5) $100 \% \mathrm{~N}+2 \mathrm{~kg}$ Biogen & 27.94 & 27.91 & 1.609 & 1.613 & 10.92 & 9.74 \\
\hline L.S.D & 0.010 & 0.056 & 0.006 & 0.006 & 0.007 & \\
\hline Lines & & & & & & \\
\hline (L1) Assiut 201 & 29.25 & 29.30 & 1.356 & 1.358 & 12.23 & 11.74 \\
\hline (L2) Assiut 202 & 29.37 & 29.37 & 1.877 & 1.874 & 9.23 & 8.78 \\
\hline (L3) Assiut 203 & 26.35 & 26.36 & 1.473 & 1.476 & 10.58 & 10.09 \\
\hline (L4) Assiut 204 & 28.67 & 28.67 & 1.804 & 1.810 & 11.76 & 11.26 \\
\hline L.S.D & 0.05 & 0.066 & 0.004 & 0.006 & 0.005 & 1.137 \\
\hline INTERACTIONS & & & & & & \\
\hline N1x L1 & 29.25 & 29.23 & 1.363 & 1.368 & 12.31 & 12.34 \\
\hline N1 $x$ L2 & 29.53 & 29.50 & 1.888 & 1.880 & 9.23 & 9.22 \\
\hline N1x L3 & 27.18 & 27.23 & 1.498 & 1.503 & 10.61 & 10.61 \\
\hline N1x L4 & 29.25 & 29.30 & 1.818 & 1.823 & 11.80 & 11.80 \\
\hline N2x L1 & 29.45 & 29.43 & 1.355 & 1.363 & 12.22 & 12.23 \\
\hline N2x L2 & 29.58 & 29.60 & 1.890 & 1.890 & 9.25 & 9.25 \\
\hline N2x L3 & 26.43 & 26.43 & 1.483 & 1.484 & 10.59 & 10.59 \\
\hline $\mathrm{N} 2 \times \mathrm{L} 4$ & 28.93 & 28.88 & 1.798 & 1.808 & 11.76 & 11.77 \\
\hline N3x L1 & 29.08 & 29.28 & 1.363 & 1.360 & 12.22 & 12.21 \\
\hline N3x L2 & 29.40 & 29.45 & 1.893 & 1.890 & 9.25 & 9.25 \\
\hline N3xL3 & 26.23 & 26.35 & 1.473 & 1.473 & 10.59 & 10.59 \\
\hline$N 3 \times L 4$ & 28.70 & 28.68 & 1.800 & 1.798 & 11.76 & 11.77 \\
\hline N4xL1 & 29.35 & 29.40 & 1.355 & 1.353 & 12.22 & 12.22 \\
\hline N4xL2 & 29.43 & 29.40 & 1.865 & 1.868 & 9.23 & 9.23 \\
\hline N4XL3 & 26.10 & 26.10 & 1.465 & 1.468 & 10.57 & 8.08 \\
\hline $\mathrm{N} 4 \times \mathrm{L} 4$ & 28.55 & 28.60 & 1.805 & 1.813 & 11.75 & 9.25 \\
\hline N5xL1 & 29.13 & 29.18 & 1.343 & 1.345 & 12.20 & 9.70 \\
\hline N5xL2 & 28.93 & 28.88 & 1.848 & 1.845 & 9.21 & 6.96 \\
\hline N5xL3 & 25.80 & 25.68 & 1.448 & 1.453 & 10.56 & 10.56 \\
\hline N5xL4 & 27.93 & 27.90 & 1.798 & 1.808 & 11.73 & 11.72 \\
\hline L.S.D & 0.120 & 0.148 & 0.009 & 0.013 & 0.012 & \\
\hline
\end{tabular}

\section{REFERENCES}

Abou El-Salehein, E.H.: M.A. Ahmed and W.A. Fekry(1999).Effect of organic and inorganic fertilizers on growth, yield and quality of potato (Solanum tuberosum L.). Egypt J. Appl. Sci., 14(1): 257-276.

Arsnault,W.D.; A.I. Dabby C.C.T. George and P. Boswell (2001). Effect of nitrogen application and seed-pieces spacing on yield and tuber size distribution in eight potato cultivars. Amer. J. potato Res. 78:301-309.

Ashour, S.A. and S.H. Sarhan(1998). Effect of organic and inorganic fertilizer on growth, yield and tuber quality of potato. J. Agric. Sci. Mansoura Univ., 23(7): 3359-3368. 
Awad, E. M.;A.A. Tartoura; H.M. El-foly and A.I. Abdel-Fattah (2002). Response of potato growth, yield and quality to farmyard manure, sulphur and gypsum levels application. $2^{\text {nd }}$ Inter. Conf. Hort. Sci.,10-12 Sept. 2002,Kafr El-Sheikh,Tanta Univ. ,Egypt.

Belanger, G.; J.R. Walsh; J.E. Richards; P.H. Miburn and N. Ziadi (2002). Nitrogen fertilization and irrigation effects on tuber characteristics of two potato cultivars. Amer. J. Potato Res. 79:No4:269-279.

El-Banna, E. N. and A.F. Tolba(2000). Effect of microbein (bio-fertilizer) and different levels of nitrogen and phosphorus on growth and yield of potato plant (Solanum tuberosum L.). J.Agric. Sci. Mansorua Univ. 25(8): 5343-5352.

El-Banna, E.N. and H.Z. Abd El-salam (2000). Effect of rock phosphate and superphosphate application with organic manures on growth, yield and quality of potato (Solanum tuberosum L.). J. Agric. Sci. Mansoura Univ.,25(7): 4531-4540.

El-Banna, E.N.; E.M. Awad; H.M. Ramadan and M.R. Mohamed(2001). Effect of bio-organic fertilization in different seasons on growth, yield and tuber quality of potato (Solanum tuberosum L.). J. Agric. Sci. Mansoura Univ., 26(3): 1687-1696.

El-Gamal, A.M.(1996). Response of potato in the newly reclaimed areas to moneral nitrogen fertilizer levels and nitrogen fixing bio-fertilizer (Halex2).Assuit j. of Agric. Sci., 27 (2): 89-99.

El-Kader, A.E. (2002). Effect of some organic and mineral fertilizers on some potato cultivars. M.Sc. Thesis, Fac. Of Agric., Mansoura Univ., Egypt.

El-Seifi, S.K.; Sawsan M.H. Sarg; A. I. Abdel-Fattah and M.A. Mohamed (2004). Effect of biofertilizers and nitrogen levels on the productivity and quality of Chinese garlic under sandy soil conditions. Zagazig J. Agric. Res., Vol. 31 No. (3) 2004.

Gommez, K.A. and A.A. Gommez (1984).Statistical procedure for Agric. Res. $2^{\text {nd }}$ ed. Johnwiley and Sons Inc. New York, 680 pages.

Hartemink, A.E.; S.O. Poloma; J.N. Sullivan; R.M. Bourke,(ed); M.G. Allen, (ed); and J.C. Salisburg (2001).Integrated nutrient management research on sweet potato at Hobu, Morobe providence. Food security for papua new guinea proceedings of the papua Hew Guind food and nutrition 2000.Conference,PNG Univ. of Tech. Late, papua New Guirean 26-30 June 2000,2001:698-711.

Kamla,S. (1999). Effect of bio-fertilizers and phosphorus levels on the production of potato (Solanum tuberosum L.) crop under north-east hill conditions. Indian J. of Agric. Sci., 69(10) 746-749.

Lee-Hsinchen, Lai-X. Ungchang, Chen Yisin, Lee-Hc, Lai Y. Chem-Y.(1996). Effect of plant spacing and nitrogen fertilizer application on the leaf tips yield of leafy sweet potato. J. Agric. Res. Of China 45:3m 230-240.

Marti $\mathrm{H}$. and H.A. Millis (2002). Nitrogen and potassium nutrition affect yield, dry weight partitioning and nutrient- use efficiency of sweet potato. Communications in soil science and plant analysis.33; 1-2:287-301.

Pandey, A. and Kumar,S. (1989). Potential of Azotobacter and azospirilla as biofertilizers for upland agriculture: a review. Jour. Of Scientific\& Industrial Research. 48(3): 134-144 (C.F. Hort.Abst. 1990,60 (2): 796). 
Badawy, A.S. et al.

Saber, M.S.M. and Gomaa, A.M.H. (1993). Associative action of multi-strain biofertilizer on tomato plant grown in newly reclaimed soil. $6^{\text {th }}$ Inter. Symp. On Nitrogen Fixation with Non-legumes. Ismailia, Egypt, 6-10 Sept., 1993: 495-497.

Singh, S.P; V. Singh and R. Lakhan(1996). Effect of phosphorus and farmyard manure application on yield, content and uptake of nitrogen, phosphorus and sulphur by potato(Solanum tubrosum L.). Indian J. Agron., 41(4): 630-632.

Sood, M.; G. Shekhawat; S. Shurana; S. Pandey and U. Chandla (1994). Effect of tillage and mode of farmyard manure application on potato growth and yield. Potato: Present \& Future Proceeding of the National Symposium held at Modipuram during March. 1-3PP. 121-123.

Taufatofua, P. Fukai, S. Cres Well; E.(ed) Asher; C.J.(ed), O'Sullivan, J.N.(1996).Effect of nitogen and water stress on growth and yield of sweet potato. Mineral nutrient discorders of root crops in the pacific: Proceddings of workshop, Nuku, alofa, Kingdom of Tonga, 17-20 April,(1995).1996m 76-79); ACIAR proceedings No. 65.

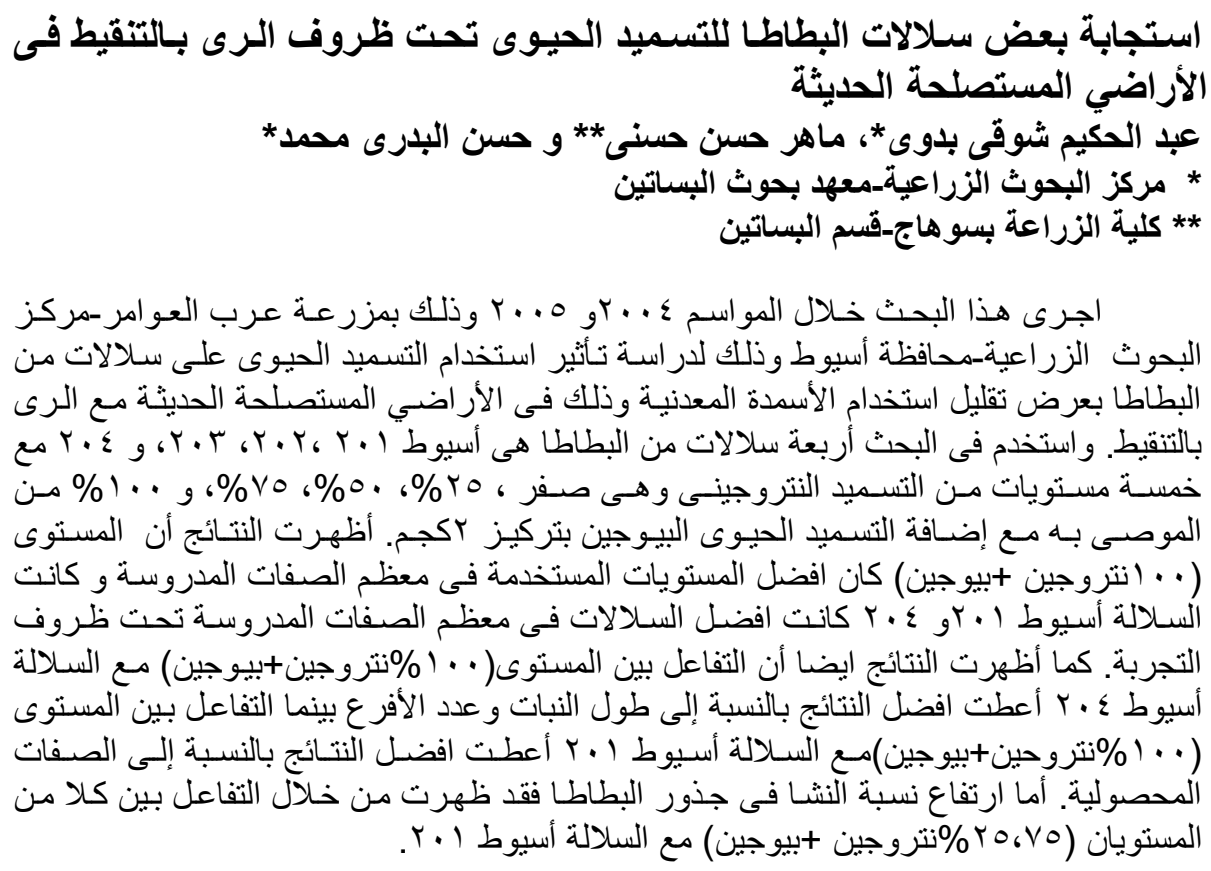


J. Agric. Sci. Mansoura Univ., 32 (4), April, 2007

273827392740274127422743274427452746

273827392740274127422743274427452746 